\title{
RUSSELL G. SCHUH: \\ A BIOGRAPHICAL PROFILE AND BIBLIOGRAPHY
}

Roxana Ma Newman

Russell Galen Schuh, affectionately known by his Hausa sobriquet as Malam Takalmi ("Mr. Shoe"), was born on March 14, 1941, in Corvalis, a small town in Oregon, although he spent most of his childhood in Klamath Falls, which he considers his hometown. Russ took an early interest in foreign languages, and earned a B.A. in French at the University of Oregon in 1963. He spent the following year at Northwestern University as a teaching assistant, earning his M.A. in French. It was there that he was introduced to the relatively new field of linguistics and began to develop his lifelong curiosity about the structural properties of the world's different languages. After his M.A., he spent a year studying linguistics at the University of California at Berkeley, where he was exposed to Asian and Native American languages. By then, he knew he was "hooked, born to be a linguist."

Not content to continue being just a student, and wanting to broaden his experience, Russ embarked on a path that he says was "the defining moment" of his life: he volunteered for the Peace Corps in 1965. He went to Niger, a francophone African country, and there he spent two years supervising adult literacy programs in the Agadez-Tahoua-Bilma region, applying his linguistics training to learn both Tamashaq, a Berber language, and Hausa, a Chadic language.

Like many returned Peace Corps volunteers, Russ came back ready to go on to graduate school. He enrolled at the University of California at Los Angeles (UCLA), which had a nationally prominent program in African studies and African linguistics, and in a year (1968) earned a second M.A., this time in linguistics. Russ supported himself at UCLA as a teaching assistant responsible for teaching all levels of Hausa. In 1969-70, he interrupted his degree program to 
return to West Africa as a research assistant for Paul Newman, who had received a National Science Foundation grant to conduct research on a number of Chadic languages in northern Nigeria. Working on this project, says Russ, gave him the research and geographical focus that he would subsequently develop over his linguistic career. Russ, accompanied by his wife Maxine, was based in Potiskum, now a thriving commercial center, but then a small town without electricity or running water. There he did research on Ngizim while Maxine collected data on Karekare, another West Chadic language. Russ's nearly 500-page dissertation on Ngizim syntax earned him a Ph.D. in 1972.

Russ stayed on at UCLA as an acting assistant professor, teaching Hausa and general linguistics, until Newman, who had been appointed director of a newly formed Centre for the Study of Nigerian Languages (CSNL) at Abdullahi Bayero College in Kano - now Bayero University - again tapped Russ to join him, this time as a research fellow of the center. Russ spent most of his two years (1973 to 1975) in Gashua, a remote town out in the bush doing ground-breaking fieldwork and writing up grammatical sketches on Bade, continuing to gather further data on Ngizim, while also learning about the little-known Manga dialect of Kanuri, a non-Chadic language. It was during those years that their first daughter Gretchen was born. (Their second daughter Elizabeth was born in the States.)

In 1975, a tenure-track position in African linguistics opened up at UCLA, for which almost all of the research staff at CSNL applied, but for which Russ was ultimately and wisely chosen. He has been there ever since, teaching with enthusiasm about the nature of language, phonological analysis, the principles of historical change, and Hausa per se. He became full professor in 1984. Over the past 30 years, Russ has made some 15 trips to West Africa, some teaching related, but mostly for field research. For example, in 1982-83, Russ accepted a visiting professorship at Ahmadu Bello University (ABU) in Zaria, teaching courses on Hausa linguistics - taught entirely in Hausa! He spent two summers in 1987 and 1988 as director of the University of California's Education Summer Abroad Program in Togo, where he also worked on two Togolese languages, and the summer of 1991 in Dakar, Senegal, where he interviewed Wolof linguists and poets and collected Wolof poetry and songs, related to his growing linguistic interest in poetic meter in West African languages.

What is immediately evident in reviewing Russ's record as a scholar is his wide intellectual curiosity about languages, his indefatigable energy as a field linguist, and his uncanny ability to write with little revision, which has permitted him to be so prolific. It is therefore no surprise that Russ has published studies on a wide array of languages. Within Chadic, he has done major work on Hausa, 
Ngizim, Miya, Bade, Bole, and Ngamo, and to a lesser extent on Bele, Galambu, Gera, Geruma, Karekare, and Kirfi, all West Chadic languages, as well as on BiuMandara (Central) Chadic languages Bura, Gude, Kilba (whose speakers he managed to locate among the international film and television students of Columbia College in Hollywood!) and Gidar, an East Chadic language. To broaden his knowledge of the Afroasiatic phylum to which Chadic belongs, Russ has taken classes at UCLA on Arabic, Hebrew, Ancient Egyptian, and Tigrinya. Among non-Chadic West African languages, he has done what he calls "a nontrivial amount of work" on Tamashaq (Berber); Fula (West Atlantic); Akposso, Avatime, and Ewe (all Kwa); Kanuri (Nilo-Saharan); and Wolof (West Atlantic), and has even published studies on some of these. Not to be confined to the languages of Africa, Russ has more recently developed a keen interest in the structures of Bulgarian, Korean, Russian, Tamil, and Turkish!

Russ's gift for understanding languages, his "no-nonsense" approach to analysis, his ability to focus his energies, and his love of writing converge in a way that enables him to write easily and clearly. I remember during the CSNL years when Russ and Maxine came to Kano for a center meeting or to get supplies that Russ would typically find a place to sit in the middle of our living room with people all around, focus his thoughts, and simply start writing, blocking out any conversation or noise going on around him. As part of his teaching, Russ often writes up short original studies of language data for his students as models for the kind of research papers he expects from them. On top of his many publications, Russ has a long list of unpublished manuscripts including a monograph-length manuscript on Gidar written in French. Many of these are available on his personal web pages.

Among the more than 100 items in the accompanying list of books, articles, reviews, and edited series that attest to Russ's energy and productivity, the following are highlighted. (Individual items are noted here by a square bracketed number.) His first book, published in 1978, consists of grammatical sketches of five previously undescribed West Chadic languages spoken in the Bauchi area [22]. This work, based on a mere four days of intensive fieldwork in five different villages, includes descriptions for each language of the verbal complex accompanied by a short wordlist. His delimited goal was to get a glimpse into certain areas of the verbal systems and provide a general phonological sketch that could be used for subgrouping purposes. His Dictionary of Ngizim (1981) [24], based on fieldwork done in 1969 and at various times from 1973 to 1975, comprises a substantial base of data from direct elicitation and transcribed texts of 
folktales, oral history, ethnography, and proverbs. The dictionary has a large Ngizim-English section and a smaller English-Ngizim wordlist.

Russ's most remarkable work is his 1998 Grammar of Miya [46], a language of the North Bauchi subgroup of West Chadic. It is a work that took many years in the making and is surely one of the most thorough descriptions of a Chadic language other than Hausa ever published. He first started work on Miya in 198283 while he was a visiting professor at $\mathrm{ABU}$, and wrote a nearly complete draft in 1987, but with teaching obligations and five years in administration, he was unable to get a final version done until 1995. In 1996, he made a final short field visit to Miya country to check some data while absorbed in a completely different project in Kano. In other published work, Russ has written a range of descriptive and historical studies on aspectual systems in verb morphology, determiner systems, phonological systems, tonal systems, language in relation to history, and metrical structures in the poetry of several African languages.

Closely related to Russ's long years of involvement with a closely-knit group of Chadic languages has been his determination to give something back to the communities that have worked so enthusiastically with him - an attitude no doubt inspired by his earlier Peace Corps experience in literacy projects. He has always sought to involve his speakers in the work that he was doing, and to consider them as collaborators, producing works together that they could use with pride of ownership. When he was in Gashua in 1973-75, he worked with educated native speakers to develop orthographies for Ngizim and Bade, which were then employed in the preparation of booklets of traditional oral literature (with Russ's own illustrations) that were printed locally for community use [93 to 96].

More recently, between 2001 and 2004, he received a three-year grant from the National Science Foundation for a "Yobe Languages Research Project" to do further research on the five Nigerian languages indigenous to Yobe State (Bade, Bole, Karekare, Ngamo, and Ngizim), working with his former Ph.D. student Alhaji Maina Gimba (Maiduguri University) and teams of educated speakers and community leaders. The primary goal was to develop good-sized, linguistically sophisticated dictionaries of each language documenting such features as derivational morphology, compounds, idioms, and loanwords. The project resulted in a remarkable set of attractively designed trilingual (with Hausa and English) dictionaries - ranging from 2,000 to 4,000 head entries-that were locally printed and published [59 to 64], works of great pride for these language communities. The linguistic value of the dictionaries lies in the methodic documentation and phonological accuracy of the data, attesting to a rich lexical store that will be useful for further research and comparative work. The Yobe 
project also produced a parallel set of oral literature readers in these languages [97 to 105]. Of this highly intensive project, Russ says he had never worked so hard, but also never felt so satisfied as when it was all accomplished.

Although the works above were locally published and are available in print form only in Nigeria, they in fact are accessible to the larger public through a graphically attractive web site at UCLA. One of Russ's most admirable scholarly qualities is his strong belief in the openness of science and sharing of knowledge. The power of the Internet provides him the perfect means to do so, and his mastery of the technology enables him to make most of his recent works freely available as downloadable pdf files and searchable lexical databases (for example, see www.humnet.ucla.edu/humnet/aflang/Yobe/yobe.html).

Given his career-long devotion to the study of "minority" Chadic languages, it is ironic that Russ is probably more broadly known for what he has done for the largest and best known Chadic language, namely Hausa. Over the 30 years that he has taught Hausa, Russ has produced a substantial output of pedagogical materials, in print and non-print media, undoubtedly more than any other linguist involved in Hausa language teaching. In 1976, he co-authored a textbook, Spoken Hausa [85], modeled on now-outdated structuralist pedagogical principles, but still in print. In the 1980s he developed computer assisted language instruction (CALI) modules for Hausa [87] (and Wolof) in the form of interactive exercises using HyperCard software. In 1990, he completed the draft of a new pedagogical grammar, "Hausa a Aikace" [Hausa in Action], co-authored with then Ph.D. student, Lawan Danladi Yalwa (Bayero University), which, though never published, was widely used by Hausa language teachers. In the mid-1990s, Russ collaborated with Abdullahi Bature (Bayero University) and Richard Randell (Stanford University) on a videofilming project in Kano that produced a set of three videotapes, edited down to five hours, featuring more than 90 short segments of natural speech in cultural contexts, controlled for grammar and vocabulary [89]. Supplementing the tapes is an enormous body of written material (transcriptions, translations, exercise manual, grammatical explanations, vocabulary) that Russ has subsequently developed and made available on a UCLA Web site [90], thus creating an integrated video-based course to teach beginning and intermediate levels of Hausa. These materials constitute one of the best video courses ever developed to teach an African language. This ambitious project, on which he has spent thousands of hours by his own reckoning and which is still evolving, is by far his most successful pedagogical work.

As if his busy agenda of research and teaching were not enough, Russ has taken on major administrative responsibilities. For example from 1989 to 1993 he 
served as chair of the UCLA Department of Linguistics, one of the largest in the country, a task he approached with the same dedication he exhibits in his scholarly work. He also devoted fifteen years (1976 to 1991) as editor of Studies in African Linguistics ( $S A L)$, the leading American journal for African linguistics.

Apart from his professional work, Russ manages to make time for personal pursuits. He has been an avid runner for years and during the past decade has participated in the Los Angeles marathon, where he came in fifth for his age group in 2002, one of his proudest moments. He considers running his major passion, doing an average of 45 miles a week, during which, he says, he does all his critical thinking about linguistics. In addition, Russ has recently resumed playing the clarinet-an instrument he had played throughout high school and college - and has been performing around the Los Angeles area for several years in a six-piece Bulgarian wedding band. The energetic, intricate rhythms and everchanging meters of Bulgarian and other Balkan music are a source of fascination and challenging to play, but if anyone would be up to the task, it would be Russ. The band has developed such a reputation that they were invited in the summer of 2005 to perform in an international folk music festival in Bulgaria.

Given Russ's creativity, energy, enthusiasm, and youthfulness of spirit, we can be sure that he will continue to be engaged in all the areas of activity that currently drive him - Chadic linguistics, poetic meters, Hausa pedagogy, running, and musical performance - and we anticipate many productive years and new forays in the future.

\section{List of Publications}

\section{A. Books and Articles}

(1) 1971. "Verb forms and verb aspects in Ngizim." Journal of African Languages 10(1):47-60. (Special Chadic Issue, ed. by Paul Newman.)

(2) 1971. "Reconstruction of the syntax of subject emphasis in certain Chadic languages." In Papers from the Second Conference on African Linguistics, ed. by Talmy Givón, pp. 67-77 (Studies in African Linguistics, Supplement 2.) Los Angeles: Dept. of Linguistics, UCLA.

(3) 1972. "Notes to a Bade dialect map." Africana Marburgensia 5(2):50-56.

(4) 1972. "Rule inversion in Chadic." Studies in African Linguistics 3:379-97. 
(5) 1974. "The linguistic situation in the Potiskum area." Africana Marburgensia 7(1):3-8.

(6) 1974. "Rubutun harshen Bade" [Bade orthography]. Harsunan Nijeriya 4:47-59.

(7) 1974. "Sound change as rule simplification? A study of consonant weakening in Kanakuru and in Hausa." In Third Annual Conference on African Linguistics, ed. by Erhard Voeltz, pp. 95-101. (I.U. Publications, African Series, 7.) Bloomington: Indiana University.

(8) 1974. "A note on inalienable possession in Hausa." Journal of West African Languages 9:113-14.

(9) 1974. "A comment on 'Rule inversion in Chadic: A reply'." Studies in African Linguistics 5:279-80.

(10) 1974 (with Paul Newman). "The Hausa aspect system." Afroasiatic Linguistics 1(1):1-39.

(11) 1974 (with Larry M. Hyman). "Universals of tone rules: evidence from West Africa." Linguistic Inquiry 5:81-115.

(12) 1974/75. "Nunation and gender in Bade." Afrika und Übersee 58:106-119.

(13) 1975. "Bode, Ngo:djin and Do:ai in the Polyglotta Africana." African Languages/Langues africaines 1:290-99.

(14) 1975. "Kandin in the Polyglotta Africana: Two languages in one." African Languages/Langues africaines 1:300-305.

(15) 1976. "The Chadic verbal system and its Afroasiatic nature." Afroasiatic Linguistics 3:1-14.

(16) 1976. "The history of Hausa nasals." In Papers in African Linguistics in Honor of Wm E. Welmers, ed. by Larry M. Hyman, Leon C. Jacobson, and Russell G. Schuh., pp 221-32. (Studies in African Linguistics, Supplement 6.) Los Angeles: Dept. of Linguistics, UCLA.

(17) 1976 (with Larry M. Hyman, Leon C. Jacobson, eds.). Papers in African Linguistics in Honor of Wm E. Welmers. (Studies in African Linguistics, Supplement 6.) Los Angeles: Dept. of Linguistics, UCLA.

(18) 1977. "Bade/Ngizim determiner system." Afroasiatic Linguistics 4(3):101174. 
(19) 1977. "West Chadic verb classes." In Papers in Chadic Linguistics, ed. by Paul Newman and Roxana Ma Newman, pp. 143-67. Leiden: AfrikaStudiecentrum.

(20) 1978. "Tone rules." In Tone: A Linguistic Survey, ed. by Victoria A. Fromkin, pp. 221-56. New York: Academic Press.

(21) 1978. "Bade/Ngizim vowels and syllable structure." Studies in African Linguistics 9:247-83.

(22) 1978. Bole/Tangale Languages of the Bauchi Area (Northern Nigeria). (Marburger Studien zur Afrika- und Asienkunde, Serie A, 13.) Berlin: Dietrich Reimer.

(23) 1980. "Paradigmatic displacement." In Historical Morphology, ed. by J. Fisiak, pp. 349-58. (Trends in Linguistics, Studies and Monographs, 17.) The Hague: Mouton.

(24) 1981. A Dictionary of Ngizim. (University of California Publications in Linguistics, 99.) Berkeley \& Los Angeles: University of California Press.

(25) 1981. "An early nineteenth century Chadic wordlist: Kallaghee." Africana Marburgensia 14(2):43-54.

(26) 1981. "Using dialect geography to determine pre-history: A Chadic case study." Sprache und Geschichte in Afrika 3:201-50.

(27) 1982. "Questioned and focussed subjects and objects in Bade/Ngizim." In The Chad Languages in the Hamito-Semitic Border Area, ed. by Herrmann Jungraithmayr, pp. 160-74. (Marburger Studien zur Afrika- und Asienkunde, Serie A, 27.) Berlin: Dietrich Reimer.

(28) 1982. "The Hausa language and its nearest relatives." Harsunan Nijeriya 12:1-24.

(29) 1983. "The evolution of determiners in Chadic." In Studies in Chadic and Afroasiatic Linguistics, ed. by Ekkehard Wolff and Hilke Meyer-Bahlberg, pp. 157-210. Hamburg: Helmut Buske.

(30) 1983. "Kilba equational sentences." Studies in African Linguistics 14:31126.

(31) 1984. "West Chadic vowel correspondences." In Current Progress in Afroasiatic Linguistics: Papers of the Third International Hamito-Semitic Congress, ed. by James Bynon, pp. 167-223. Amsterdam: Benjamins. 
(32) 1985. (editor) Précis from the Fifteenth Conference on African Linguistics. (Studies in African Linguistics, Supplement 9.) Los Angeles: Dept. of Linguistics, UCLA.

(33) 1988. "Préalable to a theory of Hausa poetic meter." In Studies in Hausa Language and Linguistics in Honour of F.W. Parsons, ed. by Graham Furniss and Philip. J. Jaggar, pp. 218-35. London: Kegan Paul International.

(34) 1989. "Long vowels and diphthongs in Miya and Hausa." In Current Approaches to African Linguistics, Vol. 5, ed. by Paul Newman and Robert. D. Botne, pp. 35-43. Dordrecht: Foris Publications.

(35) 1989. "Toward a metrical analysis of Hausa verse prosody: Mutadaarik." In Current Approaches to African Linguistics, Vol 6, ed. by I. Haïk and Laurice Tuller, pp. 161-75. Dordrecht: Foris Publications.

(36) 1989. "Gender and number in Miya." In Current Progress in Chadic Linguistics, ed. by Zygmunt Frajzyngier, pp. 171-81. (Current Issues in Linguistic Theory, 62.) Amsterdam: Benjamins.

(37) 1988/89. "The meter of Imfiraji." Harsunan Nijeriya 14:60-70.

(38) 1989. "The reality of Hausa 'Low Tone Raising': A response to Newman \& Jaggar." Studies in African Linguistics 20:253-62.

(39) 1990. "Re-employment of grammatical morphemes in Chadic: Implications for language history." In Linguistic Change and Reconstruction Methodology, ed. by Philip Baldi, pp. 599-618. (Trends in Linguistics, Studies and Monographs, 45.) Berlin: Mouton de Gruyter.

(40) 1993. (with Lawan Danladi Yalwa) "Illustrations of the IPA: Hausa." Journal of the IPA 23:77-82.

(41) 1993. "Ma'anonin hange cikakke na Hausa" [Semantics of the Hausa perfective aspect]. In Nazari a kan Harshe da Adabi da Al'adu na Hausa [Studies in Hausa Language, Literature and Culture], ed. by Abba Rufa'i, Ibrahim Yaro Yahaya, and Audu Y. Bichi, pp. 39-58. Kano: Centre for the Study of Nigerian Languages, Bayero University.

(42) 1994. "Welmers, William E. (1916-88)." Encyclopedia of Language and Linguistics, ed. by R. E. Asher and J. M. Y. Simpson, pp. 4969-70. Oxford: Pergamon Press. (Reprinted in Concise Encyclopedia of Language and Religion, ed. by J. F. A. Sawyer and J. M. Y. Simpson. Amsterdam: Elsevier (2001)). 
(43) 1995. "Aspects of Avatime phonology." Studies in African Linguistics 24:31-67.

(44) 1995. "Avatime noun classes and concord." Studies in African Linguistics 24:123-49.

(45) 1997. "The use and misuse of language in the study of African history." Ufahamu 25(1):36-81.

(46) 1998. A Grammar of Miya. (University of California Publications in Linguistics, 130.) Berkeley \& Los Angeles: University of California Press.

(47) 1999. "Metrics of Arabic and Hausa poetry." In New Dimensions in African Linguistics and Languages, ed. by Paul F. A. Kotey, pp. 121-30. (Trends in African Linguistics, 3.) Trenton: Africa World Press.

(48) 2001. "Shira, Teshena, Auyo: Hausa's (former) eastern neighbors." Sprache und Geschichte in Afrika 16/17:387-435.

(49) 2001. "Miya as a West Chadic language with V...S word order." In Von Aegypten zum Tschadsee. Eine linguistische Reise durch Afrika, Festschrift für Herrmann Jungraithmayr zum 65. Geburtstag, ed. by Dymitr Ibriszimow, Rudolf Leger, and Uwe Seibert, pp. 435-49. Würzburg: Deutsche Morgenländische Gesellschaft (Ergon Verlag).

(50) 2001 (with Lawan Danladi Yalwa). "Marking previous and implied reference in Hausa: -N/-R and DI-N." Harsunan Nijeriya 19:1-10.

(51) 2002. "Karin wak'ok'in aure na D'an Maraya Jos" [The meter of the marriage songs of Dan Maraya Jos]. In Studies in Hausa Language, Literature and Culture: The Fifth Hausa International Conference, ed. by Abdu Y. Bichi, A. U. Kafin Hausa, and Lawan Danladi Yalwa, pp. 154-63. Kano: Centre for the Study of Nigerian Languages, Bayero University.

(52) 2001 (with A. M. Gimba). "Substantive and anaphoric 'thing' in Bole, with remarks on Hausa abu/abin." In Papers in African Linguistics 1, ed. by Harold Torrence, pp. 90-122. (UCLA Working Papers in Linguistics, 6.) Los Angeles: Dept. of Linguistics, UCLA.

(53) 2002. "Palatalization in West Chadic." Studies in African Linguistics 31:97128.

(54) 2002. "Commentary on Paul Newman's 'Explaining Hausa feminines'." In Chadic and Hausa Linguistics: Selected Papers of Paul Newman with 
Commentaries, ed. by Philip J. Jaggar and H. Ekkehard Wolff, pp. 160-67. (Afrikanistische Forschungen, 12.) Cologne: Rüdiger Köppe.

(55) 2003. "Chadic overview." In Afrasian: Selected Comparative-Historical Linguistic Studies in Memory of Igor M. Diakonoff, ed. by. M. Lionel Bender and Gabor Takacs, pp. 55-60. Munich: Lincom Europa.

(56) 2003. "A comparative study of West Chadic verb suffixes." In Afrasian: Selected Comparative-Historical Linguistic Studies in Memory of Igor M. Diakonoff, ed. by. M. L. Bender and G. Takacs, pp. 71-86. Munich: Lincom.

(57) 2003. "The Linguistic influence of Kanuri on Bade and Ngizim." Maiduguri Journal of Linguistic and Literary Studies (MAJOLLS) 5:55-89.

(58) 2003. "The functional unity of the Hausa and West Chadic subjunctive." In Papers in African Linguistics 3, ed. by J. Kandybowicz, pp. 17-42. (UCLA Working Papers in Linguistics, 9.) Los Angeles: Dept. of Linguistics, UCLA. (Available at www.linguistics.ucla.edu/faciliti/wpl/issues/wpll1/wpll1.htm)

Items (59) to (64) consists of linguistically sophisticated editions of trilingual dictionaries (local language-English-Hausa) of several northeastern Nigerian languages, published locally for a local readership.

(59) 2004 (editor). Bade-English-Hausa Dictionary (Gashua Dialect), compiled by Musa Muktar Tarbutu. Potiskum: Yobe Languages Research Project.

(60) 2004 (editor). Bade-English-Hausa Dictionary (Western Dialect), compiled by Bala Wakili Dagona. Potiskum, Nigeria: Yobe Languages Research Project.

(61) 2004 (editor). Bole-English-Hausa Dictionary, compiled by Alhaji Maina Gimba, Malam Baba Ali, and Madu Bah. Potiskum: Yobe Languages Research Project.

(62) 2004 (editor). Karekare-English-Hausa Dictionary, compiled by Malam Kariya Gambo and Malam Umaru Manu Karofi. Potiskum: Yobe Languages Research Project.

(63) 2004 (editor). Ngamo-English-Hausa Dictionary, compiled by Isa Adamu Gashinge, Jibir Audu Janga Dole, and Umaru Mamu Goge. Potiskum: Yobe Languages Research Project. 
(64) 2004 (editor) Ngizim-English-Hausa Dictionary, compiled by Ahmed Mohammed Bedu, Joseph Ya'u Yakubu, Mohammed Alhaji Adamu, and Usman Babayo Garba. Potiskum: Yobe Languages Research Project.

(65) 2005. "Degemination, compensatory lengthening, and gemination in Gudi Ngamo." In Papers in Phonology 6, ed. by Jeffrey Heinz, Andy Martin, and Katya Pertsova, pp. 1-11. (UCLA Working Papers in Linguistics, 11.) Los Angeles: Dept. of Linguistics, UCLA.

(66) in press. "Bade morphology." In Morphologies of Asia and Africa, ed. by Alan S. Kaye, Winona Lake, IN: Eisenbrauns.

\section{B. Reviews and Review Articles}

(67) 1974. "Review of Tamazight Verb Structure by Ernest T. Abel-Massih." American Anthropologist 76:452-53.

(68) 1977. "Review of An Introduction to Linguistics by Bruce L. Liles." Language 53:493-94.

(79) 1978. "Review of Linguistics and Bilingual Dictionaries by A. M. AlKasimi.” Language 54:236-37.

(70) 1978. "Review of Einführung in die Hausa-Sprache (Kursus für Kolleg und Sprachlabor) by H. Jungraithmayr and W. J. G. Möhlig.” Language 54:246-47.

(71) 1979. "Review of Analogy by R. Anttila." The Modern Language Journal 63:233-34.

(72) 1979. "Review of The Case for Fricative-Laterals in Proto-Semitic by R. C. Steiner." Language 55:256.

(73) 1979. "Review of Harsusi Lexicon and English: Harsusi Word-List by T. M. Johnstone." Language 55:747-48.

(74) 1980. "Review of Cinq textes tchadiques, ed. by H. Jungraithmayr and J.-P. Caprile.” Language 56:666-69.

(75) 1982. "Review of Ferdinand de Saussure by J. Culler." Language 58:72526.

(76) 1982. "Review of Roots by P. Davies." Language 58:726.

(77) 1982. "Review of Die Morphologie des Verbs im Ost-Dangaleat (Guéra, Tschad) by Carl Ebobissé." Afroasiatic Linguistics 8(4):30-31. 
(78) 1982. "Review of Struktur und Wandel afrikanischer Sprachen ed. by H. Jungraithmayr." Afroasiatic Linguistics 8(4):31-32.

(79) 1982. "Review of Chadic Word Lists by C. H. Kraft." Afroasiatic Linguistics $8(4): 33$.

(80) 1988. "Review of A Grammar of the Lamang Language by Ekkehard Wolff." Bulletin of the School of Oriental and African Studies 51:388-89.

(81) 1996. "Review of by Chadic Lexical Roots by Herrmann Jungraithmayr and Dymitr Ibriszimow." Afrika und Übersee, 79:129-35.

(82) 1996. "Review of Bole Language and Documentation Unit (BOLDU) Report $I$ by Dymitr Ibriszimow and Alhaji Maina Gimba." Bulletin of the School of Oriental and African Studies 59:620-21.

(83) 1998. "Review of Wörterbuch Hausa-Deutsch by Irmtraud Herms." Journal of African Languages and Linguistics 19:183-86.

(84) 2002. "Review of African Languages: An Introduction by Bernd Heine and Derek Nurse." General Linguistics 39:97-103.

\section{Pedagogical Works, Print and Non-Print Media}

(85) 1976 (with J R. Cowan). Spoken Hausa. Ithaca, NY: Spoken Language Services, Inc. (Translated into French by Bernard Caron as Exercices de pratique orale. Paris: Institut National des Langues et Civilisations Orientales, 1981.)

(86) 1986. "How should we teach Hausa?" In The Design and Evaluation of African Language Learning Materials, ed. by D. Dwyer, pp. 67-77. East Lansing, MI: African Studies Center, Michigan State University.

(87) 1989-1991 (with A. Wysocki and Lawan Danladi Yalwa). CALI Excercises for Hausa. (Twenty interactive multi-media computerized exercises in HyperCard.

(88) 1989-1991 (with A. Wysocki and Dieynaba Gaye). CALI Excercises for Wolof. (Twenty interactive multi-media computerized exercises in HyperCard.)

(89) 1996-1998 (with Abdullahi Bature and Richard Randell). Hausar BakaGani Ya Kori Ji [Oral Hausa-A Picture is Worth 1000 Words]. (Series of three videotapes for elementary and intermediate study of Hausa.) Windsor CA: World of Languages, Incorporated. (Available from East Bay Media Center, Berkeley, CA.) 
(90) 1996-present. Hausa. (Evolving Web site on the Hausa language, including materials related to (89) and other grammatical, dialectal, cultural, as well as reference information.) www.humnet.ucla.edu/humnet/aflang/Hausa/.

(91) 2000 (with W. R. Leben). "Multimedia learning materials for African languages." Journal of the African Language Teachers Association 1(2):51-65.

(92) 2001. "Easy development of multi-media language teaching materials using QuickTime Pro." Journal of African Language Learning and Teaching 1:143-64.

\section{Language Texts Series}

Served as project designer, supervisor, translator, and editor of primary language text collections of the verbal arts (proverbs, riddles, songs) in different languages of northeastern Nigeria, published locally and designed for a local readership.

(93) 1974 (editor). Tarzanan' Amsi [Tales from Amshi] (in the Bade language). Kano: Centre for the Study of Nigerian Languages.

(94) 1974 (editor). Mimin' Yin [Tales from Yin] (in the Bade language). Kano: Centre for the Study of Nigerian Languages.

(95) 1975 (editor). Tamtamen' Ado [Tales from the South] (in the Bade language). Kano: Centre for the Study of Nigerian Languages.

(96) 1975 (editor). Tarzanako, Mimiko, Tamtəmeko do Makaranta Gasiwa [Here's a Tale, Here's a Tale, Here's a Tale from Gashua School] (in the Bade language). Kano: Centre for the Study of Nigerian Languages. (Reprinted in 2004 by the Yobe Languages Research Project.)

Items (97) to (105) are collections of folktales in five languages of Yobe State. The texts with line-by-line English translations can be downloaded in pdf format from www.humnet.ucla.edu/humnet/aflang/Yobe/yobe.html.

(97) 2003 (editor). Terzena Gabade [Tales in the Bade Language]. Potiskum: Yobe Languages Research Project.

(98) 2003 (editor). Dindi Bo Pikka ko gama Yagana Amma Mazawun [Tales in the Bole Language from Yagana Amma Mazawun]. Potiskum: Yobe Languages Research Project.

(99) 2003. (editor). Dindeno ka gi ma Malam Kariya Gambo [Tales from Malam Kariya Gambo] (in the Karekare language). Potiskum: Yobe Languages Research Project. 
(100) 2003 (editor). Dintir Bo Ngamo [Tales in the Ngamo Language]. Potiskum: Yobe Languages Research Project.

(101) 2003 (editor). Zenzen da rik Adamu Helman Sale [Tales from Adamu Helman Sale] (in the Ngizim language). Potiskum: Yobe Languages Research Project.

(102) 2004 (editor). Komno Bo Bole [Verbal Arts in the Bole Language], compiled by Alhaji Maina Gimba, Malam Baba Ali, and Madu Bah. Potiskum: Yobe Languages Research Project.

(103) 2004 (editor). Asim ma Bo Karai-Karai [Verbal Arts in the Karekare Language], compiled by Malam Kariya Gambo, Malam Umaru Manu Karofi, and Rifkatu I. Bumi. Potiskum: Yobe Languages Research Project.

(104) 2004 (editor). Asum Bo Ngamo [Verbal Arts in the Ngamo Language], compiled by Isa Adamu Gashinge, Jibir Audu Janga Dole, and Umaru Mamu Goge. Potiskum: Yobe Languages Research Project.

(105) 2004 (editor). Gamzazegai Gagaya Ngezem [Verbal Arts in the Ngizim Language], compiled by Ahmed Mohammed Bedu, Joseph Ya'u Yakubu, Mohammed Alhaji Adamu, and Usman Babayo Garba. Potiskum: Yobe Languages Research Project.

Roxana Ma Newman

Indiana University

email: rmnewman@indiana.edu 
